\title{
Fas mediated apoptosis of human Jurkat T-cells: intracellular events and potentiation by redox-active $\alpha$-lipoic acid
}

\author{
Chandan K. Sen ${ }^{\star, 1,3}$, Sashwati Roy ${ }^{2,3}$ and Lester Packer ${ }^{2}$ \\ 1 Biological Technologies, Lawrence Berkeley National Laboratory, Berkeley, \\ California, USA \\ 2 Department of Molecular and Cell Biology, University of California, Berkeley, \\ CA 94720-3200 USA \\ ${ }^{3}$ Department of Physiology, University of Kuopio, Finland \\ * corresponding author: CK Sen, 251 Life Sciences Addition, Department of \\ Molecular and Cell Biology, University of California, Berkeley, CA 94720-3200 \\ U.S.A. tel: 510642 4445; fax: 510644 2341; \\ e-mail: cksen@socrates.berkeley.edu
}

Received 9.11.98; revised 25.01.99; accepted: 25.02.99

Edited by: A. Finazzi-Agró

\begin{abstract}
Activation of caspases is required in Fas receptor mediated apoptosis. Maintenance of a reducing environment inside the cell has been suggested to be necessary for caspase activity during apoptosis. We explored the possibility to potentiate Fas mediated killing of tumor cells by $\alpha$-lipoic acid (LA), a redox-active drug and nutrient that is intracellularly reduced to a potent reductant dihydrolipoic acid. Treatment of cells with $100 \mu \mathrm{M}$ LA for $72 \mathrm{~h}$ markedly potentiated Fas-mediated apoptosis of leukemic Jurkat cells but not that of peripheral blood lymphocytes from healthy humans. In Jurkat, Fas activation was followed by rapid loss of cell thiols, decreased mitochondrial membrane potential, increased $\left[\mathrm{Ca}^{2+}\right]_{i}$ and increased PKC activity; all these responses were potentiated in LA pretreated cells. PKC $\delta$ played an important role in mediating the effect of LA on Fas-mediated cell death. In response to Fas activation LA treatment potentiated caspase 3 activation by over $100 \%$. The ability of LA to potentiate Fas mediated killing of leukemic cells was abrogated by a caspase 3 inhibitor suggesting that increased caspase 3 activity in LAtreated Fas-activated cells played an important role in potentiating cell death. This work provides first evidence showing that inducible caspase 3 activity may be pharmacologically up-regulated by reducing agents such as dihydrolipoic acid.
\end{abstract}

Keywords: antioxidant; calcium; caspase; cell death; protein kinase c; signal transduction

Abbreviations: $\left[\mathrm{Ca}^{2+}\right]_{\mathrm{i}}$, intracellular calcium ion concentration; CHAPS, 3-[(3-cholamidopropyl)-dimethylammonio]-1-propane sulfonate; $\mathrm{CH} 11$, agonistic Fas IgM Ab; DHLA, dihydrolipoate; D-PBS, Dulbecco's PBS, pH 7.4; Fas+, Fas bearing; FasL, Fas ligand; ICE, interleukin-1b converting enzyme; IMDM, Isocove's modified Dulbecco medium; JC-1, 5,5,6,6-tetrachloro-1,1,3,3-tetraethylben- zimidazolcarbocyanine iodide; LA, $\alpha$-lipoic acid or 6,8 , thioctic acid; MBB, monobromobimane; PI, propidium iodide; PKC, protein kinase C; TdT, terminal deoxynucleotidyl transferase; TUNEL, TdT mediated nick end labeling

\section{Introduction}

The transmembrane Fas $\mathrm{Ag}$ is a member of the tumor necrosis factor/nerve growth factor receptor family which can trigger apoptosis. Interaction between Fas-Fas ligand (FasL) ${ }^{2}$ transduces apoptotic signals in sensitive target cells. This pathway to induce programmed cell death has been suggested to be of potential use in cancer treatment. Treatment with anti-Fas Ab has been shown to suppress the growth of Fas bearing (Fas+) tumor cells. ${ }^{1}$ Also, malignant glioma cells are susceptible to Fas mediated apoptosis triggered by agonistic $A b^{2}$ The killing of myelogenous leukemia cells by the Fas/FasL pathway has the remarkable potential of serving as a novel and effective approach for leukemia immunotherapy. ${ }^{3}$ Proliferation of vascular smooth muscle cells in response to injury plays a central role in the pathogenesis of vascular disorders. FasL gene transfer to the wall of blood vessel induced apoptosis of Fas+ vascular smooth muscle cells and inhibited neointima formation in injured rat carotid artery. ${ }^{4}$ Thus, Fas mediated apoptosis is expected to have marked therapeutic potential in certain disorders.

In contrast to the apoptosis triggering role of reactive oxygen species observed in several cell systems 5,6 superoxide anion functions as a natural inhibitor of Fas mediated cell death. ${ }^{7}$ Hydrogen peroxide has been also observed to delay Fas mediated apoptosis. ${ }^{8}$ Nitric oxide, another reactive species, is also known to inhibit Fas mediated apoptosis. ${ }^{9}$ Activation of cysteine death proteases, caspases, is required for commitment to Fas mediated apoptosis. ${ }^{10}$ Recent studies have hypothesized that maintenance of a reducing environment inside the cell is necessary for caspase activity during apoptosis. ${ }^{8}$ Consistently, chemical agents that block or cause oxidation of intracellular thiols have been shown to inhibit Fas mediated apoptosis. ${ }^{11,12}$ There is no report, however, showing that increased reducing environment of the cell could facilitate Fas mediated apoptosis.

Intracellular thiols are known to play a central role in the regulation of redox sensitive signal transduction. ${ }^{13,14}$ $\alpha$-Lipoic acid (LA), also known as thioctic acid (1,2 dithiolane-3-pentanoic acid), is a sulfur containing antioxidant that is widely used as a dietary supplement and as a drug to treat diabetic complications. ${ }^{15}$ Trace amounts of LA naturally occurring in human tissues are present in $\alpha$-keto acid dehydrogenase complexes where it is covalently bound to a protein-lysyl residue. ${ }^{16}$ Exogenously supple- 
mented LA is readily taken up by a variety of cells and tissues where it is rapidly reduced by NADH or NADPH dependent enzymes to dihydrolipoate (6,8 dithiooctanoic acid, DHLA). ${ }^{17,18}$ Significant accumulation of intracellular DHLA in LA treated Jurkat cells has been previously shown in several studies. ${ }^{18-20}$ DHLA is a strong reductant with a two electron reduction potential of $-0.32 \mathrm{~V} .{ }^{21}$ It is known to regenerate major physiological antioxidants of lipid and aqueous phases such as vitamin $\mathrm{E}$, ascorbate and glutathione. ${ }^{16} \mathrm{~A}$ remarkable ability of LA to enhance the content of reduced thiols in Jurkat T-cells and to thus alter intracellular thiol redox status has been found. ${ }^{22}$ Because LA is a commonly used nutritional supplement and a clinical drug that is known to result in the intracellular generation of the potent reducing agent DHLA, we sought to investigate whether Fas mediated apoptosis in leukemic Jurkat cells could be potentiated by treatment with LA. Jurkat cell has been the most widely used model to study Fas-induced apoptosis and caspase 3 was first described in this cell line. $8,10,23-26$ The possible effect of LA on Fas $\mathrm{Ag}$ activated peripheral blood lymphocytes (PBL) isolated from healthy human was also examined.

\section{Results}

\section{Potentiation of Fas mediated apoptosis in leukemic Jurkat T-cells by $\alpha$-lipoic acid}

Following activation of Jurkat T-cells by the agonist $\mathrm{Ab} \mathrm{CH} 11$ rapid externalization of membrane phosphatidylserine was observed. In cells pretreated with $100 \mu \mathrm{M}$ LA for $72 \mathrm{~h}$ membrane phosphatidylserine externalization was markedly accelerated (Figure 1). Loss of cell viability following $\mathrm{CH} 11$ activation of Jurkat T-cells was a delayed response that followed membrane phosphatidylserine externalization. Until the $2 \mathrm{~h}$ time point following treatment of cells with $\mathrm{CH} 11$ no loss of cell viability was observed as studied by the propidium iodide exclusion assay. A remarkable loss of cell viability was noted in cells that were activated for $4 \mathrm{~h}$. Consistent with the potentiating effect of $\mathrm{LA}$ on $\mathrm{CH} 11$ induced membrane
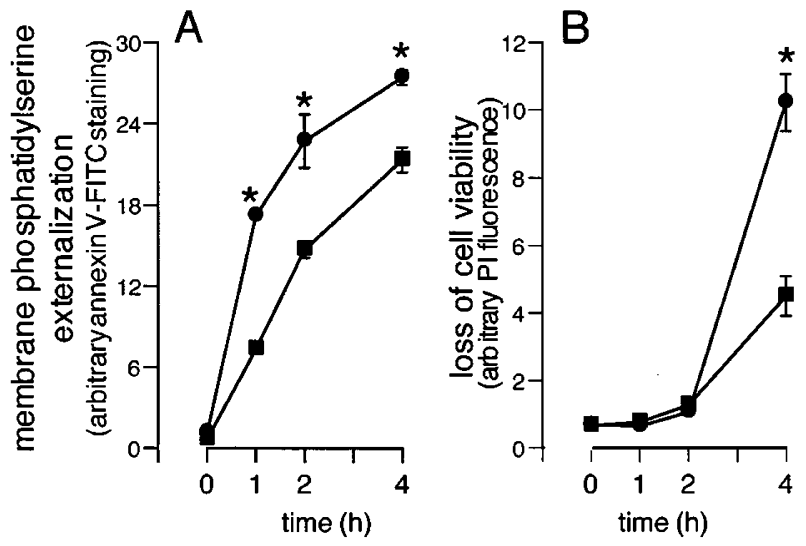

Figure 1 Potentiation of Fas mediated apoptosis in Jurkat cells by LA treatment. (A) Time course of membrane phosphatidylserine externalization; (B) loss of cell viability as determined by the inability of cells to exclude propidium iodide (PI). Cells were either not (squares) or treated (circles) with $100 \mu \mathrm{M}$ LA for $72 \mathrm{~h}$. Cells in culture were either not $(0 \mathrm{~h})$ or treated with the agonistic $\mathrm{Ab} \mathrm{CH} 11$ (200 ng/ml) for the indicated duration. Mean fluorescence values obtained from at least 10000 cells are plotted. Data are mean \pm S.D. Effect of LA treatment compared to the corresponding LA non-treated value: ${ }^{\star} P<0.001$
A

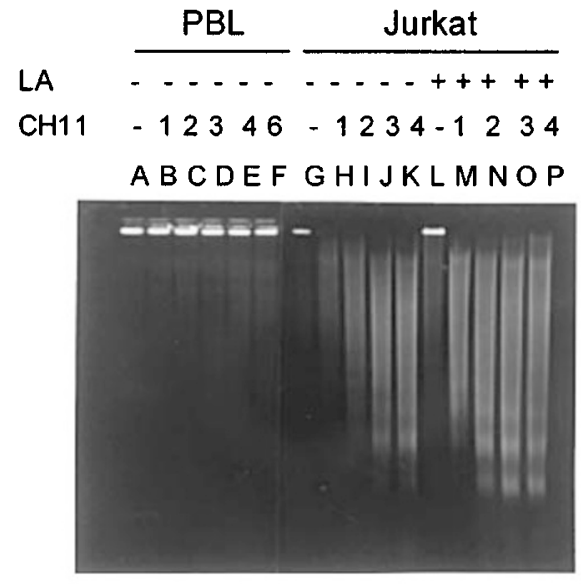

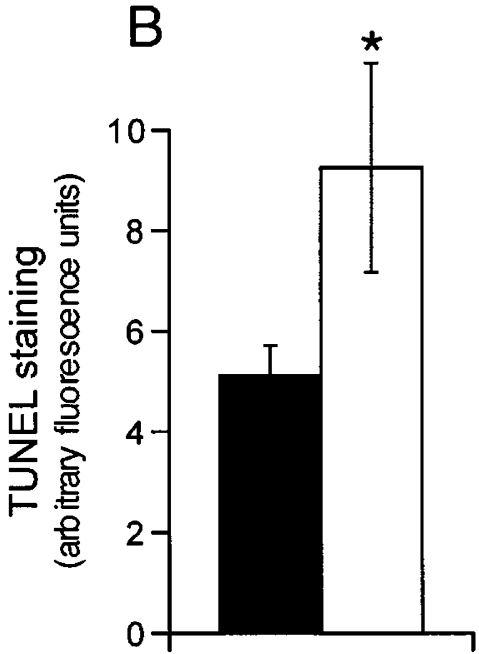

Figure 2 Potentiation of Fas mediated DNA fragmentation in Jurkat cells by LA treatment. (A) The effect of CH11 (200 ng/ml) treatment on DNA integrity of peripheral blood lymphocytes (lanes A-F) and Jurkat cells (lanes $\mathrm{G}-\mathrm{P}$ ). LA, $100 \mu \mathrm{M}, 72 \mathrm{~h}$ before $\mathrm{CH} 11$ treatment. The duration of $\mathrm{CH} 11$ treatment is indicated in hours. (B) Quantitative analysis of the effect of LA treatment on Fas mediated apoptosis in Jurkat cells. Cells were either not (solid bar) or treated (open bar) with $100 \mu \mathrm{M} \mathrm{LA}$ for $72 \mathrm{~h}$. After this, cells were treated with $200 \mathrm{ng} / \mathrm{ml}$ of the agonistic Ab CH11 for $4 \mathrm{~h}$. DNA fragmentation was quantitated by terminal deoxynucleotidyl transferase mediated nick end labeling. Mean \pm S.D. of arbitrary mean fluorescence units are plotted. ${ }^{*} P<0.001$ compared to the corresponding LA non-treated cells 
phosphatidylserine externalization, LA treated Jurkat cells were more susceptible to Fas receptor activation dependent death compared to cells that were not treated with LA (Figure 1). A dose $(25-100 \mu \mathrm{M})$ dependent effect of LA on potentiating Fas mediated Jurkat cell death was observed (not shown).

Under the conditions used in this study the agonist $A b$ that activates the Fas receptor, $\mathrm{CH} 11$, did not trigger apoptosis in PBL. This was confirmed by phosphatidylserine staining, propidium iodide dependent cell viability assay (not shown) as well as DNA integrity assay on agarose gel. Also, LA alone or in combination with $\mathrm{CH} 11$ did not influence DNA integrity in PBL (Figure 2A). However, in Jurkat cells $\mathrm{CH} 11$ treatment resulted in rapid loss of DNA integrity and laddering. The kinetics of this apoptosis response was clearly accelerated in cells that were pretreated with LA for $72 \mathrm{~h}$ (Figure 2A). The potentiating effect of LA on $\mathrm{CH} 11$ induced DNA fragmentation in Jurkat cells was quantitatively confirmed using the TUNEL assay (Figure 2B) as well as by the flow cytometric determination of DNA fragmentation (Figure 3 ).

\section{Fas receptor expression in lymphocytes freshly isolated from healthy human and acute leukemic Jurkat cells}

Immunostaining for the presence of Fas receptor showed that while approximately $35 \%$ of $\mathrm{PBL}$ stained positive almost $100 \%$ of Jurkat cells contain the receptor (Figure $4 \mathrm{~A}$ ). When
PBL and Jurkat cells were stained to study the abundance of the receptor, it was observed that the density of Fas receptor on the Jurkat cells was much higher than that in PBL. LA treatment to PBL or Jurkat did not influence the expression of Fas (Figure 4B).
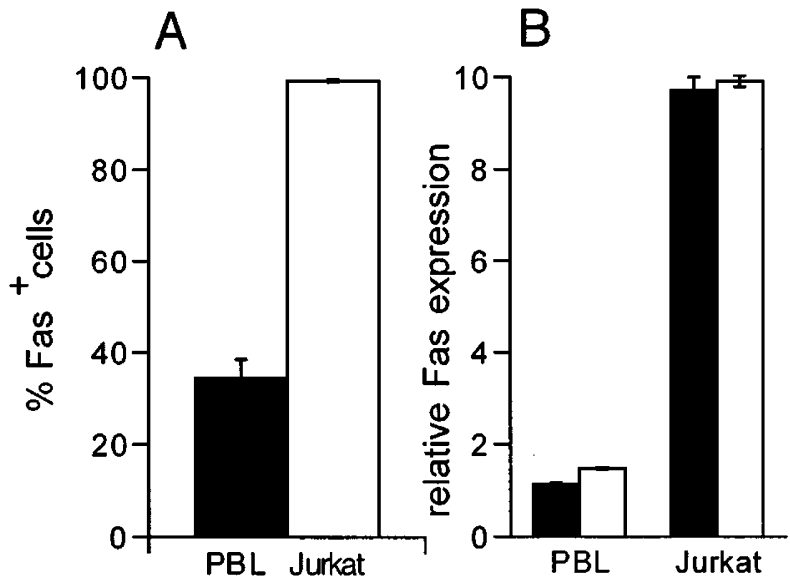

Figure 4 Expression of Fas $\mathrm{Ag}$ in peripheral blood lymphocytes (PBL) and Jurkat cells. (A) Illustrates the percentage of the whole population of cells that stained positive for the presence of the Fas Ag. (B) Illustrates the total amount of Fas Ag present in PBL and Jurkat. Cells were either not (open) or treated (solid) with $100 \mu \mathrm{M}$ LA for $72 \mathrm{~h}$. Mean \pm S.D. of arbitrary mean fluorescence units are plotted
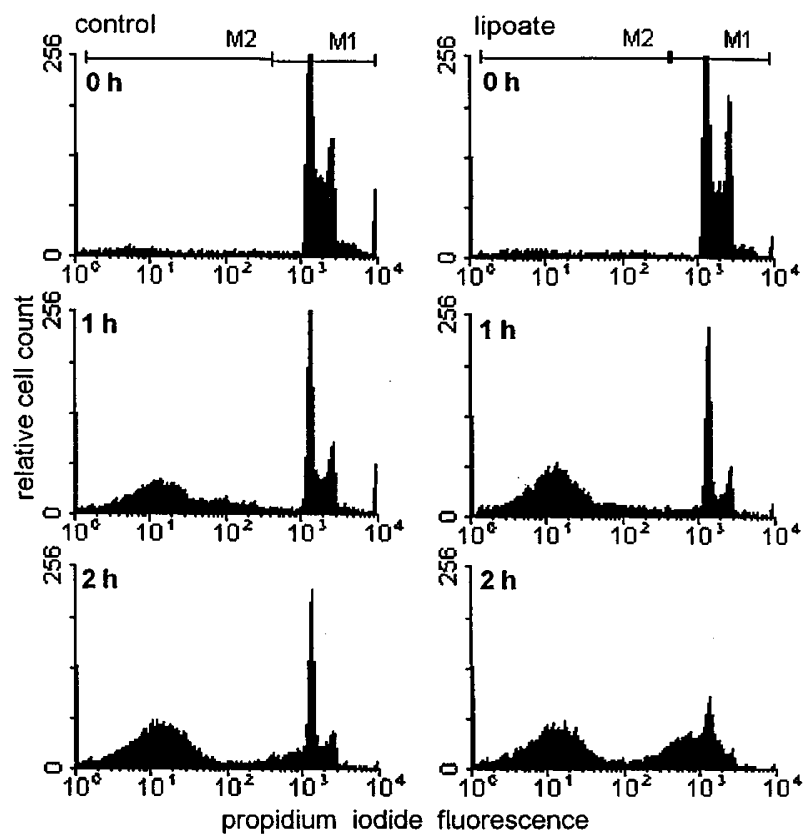

Figure 3 Flow cytometric determination of DNA fragmentation in Jurkat cells. Cells were either not (left column) or treated (right column) with $100 \mu \mathrm{M} \mathrm{LA}$ (lipoate) for $72 \mathrm{~h}$. After this, cells were either not (top row) or treated (middle and bottom row) with $200 \mathrm{ng} / \mathrm{ml} \mathrm{CH} 11$ for the indicated time interval. Propidium iodide fluorescence was collected from permeabilized cells. Intact DNA (region M1) and fragmented DNA (region M2) signals are shown in the histogram

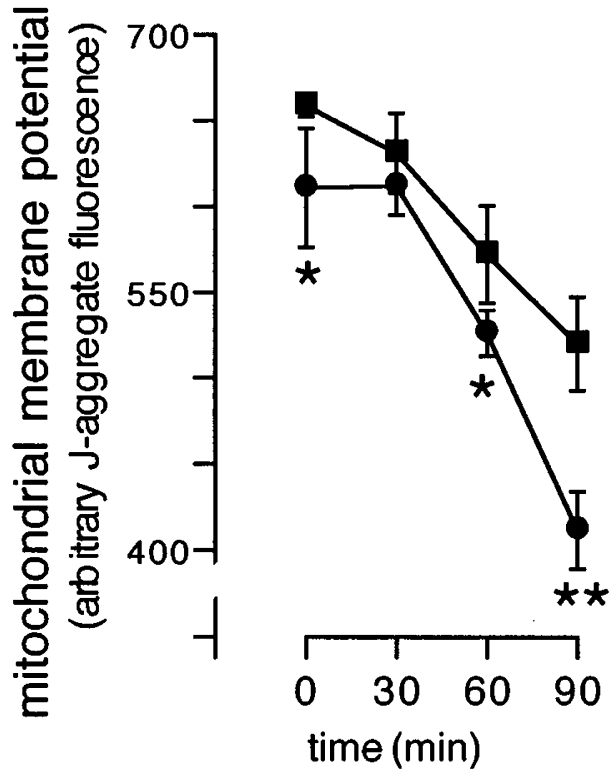

Figure 5 Mitochondrial membrane depolarization following activation of the Fas receptor in Jurkat cells. Cells were either not (square) or treated (circle) with $100 \mu \mathrm{M}$ LA for $72 \mathrm{~h}$. After this treatment, cells were treated or not $(0 \mathrm{~min})$ with the agonistic $\mathrm{Ab} \mathrm{CH} 11(200 \mathrm{ng} / \mathrm{ml})$ for the indicated duration. Mitochondrial membrane potential was measured on the basis of $\mathrm{J}$-aggregate formation in JC-1 loaded cells. LA treatment accelerated $\mathrm{CH} 11$ induced loss of membrane potential. ${ }^{*} P<0.05$ and ${ }^{\star \star} P<0.001$ compared to corresponding LA non-treated cells 


\section{Mitochondrial function}

Loss of mitochondrial membrane potential as indicated by $\mathrm{J}$ aggregate formation was one of the earliest intracellular changes following $\mathrm{CH} 11$ induced Fas receptor activation. Within $1 \mathrm{~h}$ of such activation a marked loss of mitochondrial membrane potential was observed. Cells pretreated with $100 \mu \mathrm{M}$ LA for $72 \mathrm{~h}$ showed a significantly lower mitochondrial function. Following 90 min of Fas-receptor activation, mitochondrial function was significantly lower in LA-treated cells compared to that in non-treated control cells (Figure 5).

\section{Intracellular $\mathrm{Ca}^{2+}$ changes}

In $\mathrm{CH} 11$ induced Fas activated Jurkat cells, the loss of mitochondrial function was associated with increase in intracellular calcium ion concentration $\left(\left[\mathrm{Ca}^{2+}\right]_{\mathrm{i}}\right)$. Figure $6 \mathrm{~A}$ illustrates graphic representation of results obtained from indo-1 loaded cells. The $X$-axis represents cell size, and the $\mathrm{Y}$-axis represents unbound/bound indo-1 ratio. A downward deflection of the signal along the $\mathrm{Y}$-axis reflects increased $\left[\mathrm{Ca}^{2+}\right]_{\mathrm{i}}$; and a left-ward shift of the signal along the $\mathrm{X}$-axis represents cell shrinking, a characteristic feature of apoptosis. Using this form of measurement we were able to directly relate changes in $\left[\mathrm{Ca}^{2+}\right]_{\mathrm{i}}$ with apoptosis. Figure $6 \mathrm{Aa}$ shows that under resting conditions the $\left[\mathrm{Ca}^{2+}\right]_{i}$ is maintained at a relatively low level. After activation of cells with $\mathrm{CH} 11$, a clear downward shift of the signal is observed (Figure 6Ab) suggesting increasing $\left[\mathrm{Ca}^{2+}\right]_{\mathrm{i}} 60 \mathrm{~min}$ after activation. This effect is more remarkable 90 min after activation (Figure 6Ac) where elevation of $\left[\mathrm{Ca}^{2+}\right]_{i}$ is followed by cell shrinking. The effect of $\mathrm{CH} 11$ on $\left[\mathrm{Ca}^{2+}\right]_{i}$ of LA treated cells is shown (Figure $6 A c$ and f). LA treatment alone did not cause any significant change in baseline $\left[\mathrm{Ca}^{2+}\right]_{\mathrm{i}}$ (Figure 6Ad). However, $\mathrm{CH} 11$ induced increase in $\left[\mathrm{Ca}^{2+}\right]_{i}$ was accelerated in $\mathrm{LA}$ treated cells compared to LA non-treated cells (compare Figure 6Ab vs Ae and $A c$ vs Af). This is more clearly evident from Figure $6 B$ where the data have been quantitatively plotted. Figure $6 \mathrm{Ae}$ and Af clearly show a right-angle effect indicating that Fas activation induced cell shrinkage is preceded by elevation of $\left[\mathrm{Ca}^{2+}\right]_{i}$.

\section{Protein kinase $\mathbf{C}$ (PKC) activation}

Elevated $\left[\mathrm{Ca}^{2+}\right]_{i}$ in $\mathrm{CH} 11$ activated Jurkat cells was accompanied with marked activation of cellular PKC (Figure 7A). $\mathrm{CH} 11$ induced PKC activation was markedly enhanced in cells that were treated with LA. Rottlerin, a PKC $\delta$ inhibitor at the concentration used, ${ }^{31}$ significantly inhibited $\mathrm{CH} 11$ induced loss of cell viability. In PKC $\delta$ inhibited cells, the ability of LA to potentiate Fas receptor mediated cell death was markedly diminished (Figure 7B).
A

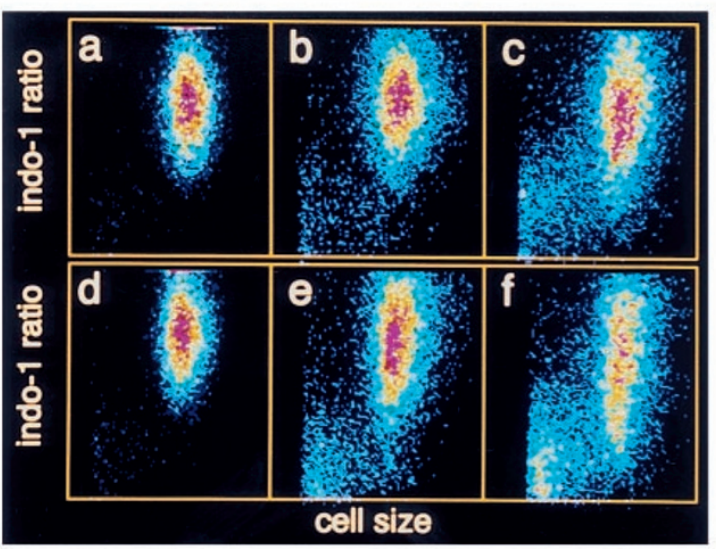

B

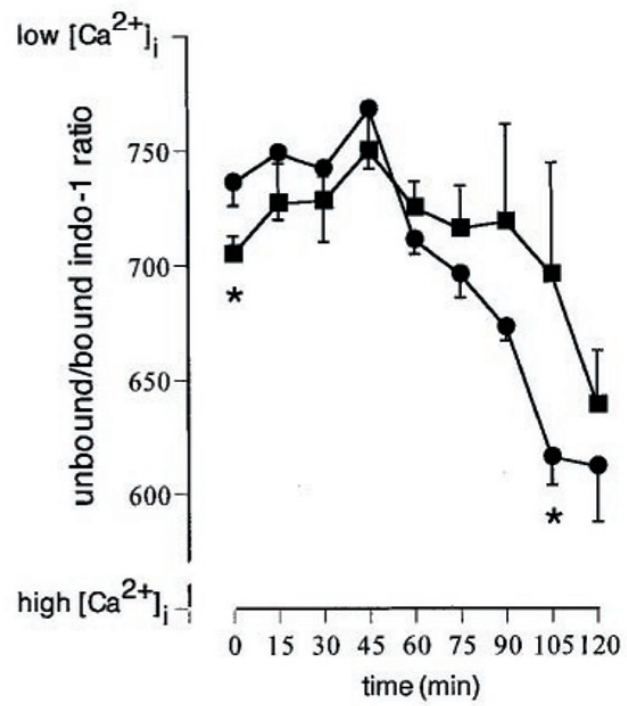

Figure 6 Increased intracellular $\mathrm{Ca}^{2+}$ in Fas activated Jurkat T-cells. (A) Dot plots showing that cell shrinking, a characteristic feature of apoptosis, is preceded by increase in intracellular $\mathrm{Ca}^{2+}$ in Fas activated cells. Cells were either not $(\mathbf{a}-\mathbf{c})$ or treated $(\mathbf{d}-\mathbf{f})$ with $100 \mu \mathrm{M}$ LA for $72 \mathrm{~h}$. After this treatment, cells were treated or not (a and $\mathbf{d})$ with the agonistic Ab CH11 $(200 \mathrm{ng} / \mathrm{ml})$ for $1 \mathrm{~h} \mathrm{(b}$ and $\mathbf{e})$ or $1.5 \mathrm{~h}$ (c and $\mathbf{f})$. In each frame, the X-axis represents forward scatter or cell size and the $Y$ axis represents unbound/bound indo-1 ratio. A leftward shift of signal along the X-axis indicates decrease in cell size or shrinking, and a downward shift of the signal indicates increased intracellular $\mathrm{Ca}^{2+}$. Experiments were carried out in the presence of $1 \mathrm{mM}$ EGTA. Thus, increased intracellular Ca ${ }^{2+}$ is mainly contributed by $\mathrm{Ca}^{2+}$ mobilized from intracellular pools. The colours represent the relative cell number. From the violet to the red end of the visible spectrum colors represent progressively increasing cell densities. Intracellular $\mathrm{Ca}^{2+}$ was followed in indo 1 loaded cells. This illustration was prepared using the software Multiplus (Phoenix Flow Systems, San Diego, CA, USA). (B) Kinetics of increase in intracellular $\mathrm{Ca}^{2+}$ following activation of Fas. Cells were either not (square) or treated (circle) with $100 \mu \mathrm{M}$ LA for $72 \mathrm{~h}$. After this treatment, cells were treated or not $(0 \mathrm{~min})$ with the agonistic Ab $\mathrm{CH} 11(200 \mathrm{ng} / \mathrm{ml})$ for the indicated duration. Intracellular Ca ${ }^{2+}$ was estimated from indo-1 loaded cells as described above. Data are mean \pm S.D. ${ }^{\star} P<0.001$ compared to the corresponding LA non-treated cells 


\section{Cellular thiols}

Almost concurrent with the loss of mitochondrial function and elevation of $\left[\mathrm{Ca}^{2+}\right]_{i}$ loss of cellular thiols was observed in Fas activated Jurkat cells (Figure 8 ). Remarkable loss of total reduced protein thiol was a rapid response that reached a maximum within $80 \mathrm{~min}$ of Fas activation (Figure $8 \mathrm{~A}$ ). Activation of Fas also resulted in loss of GSH from the cells. Treatment of Jurkat cells with LA for $72 \mathrm{~h}$ increased cell GSH content. However, Fas activation dependent loss of GSH from
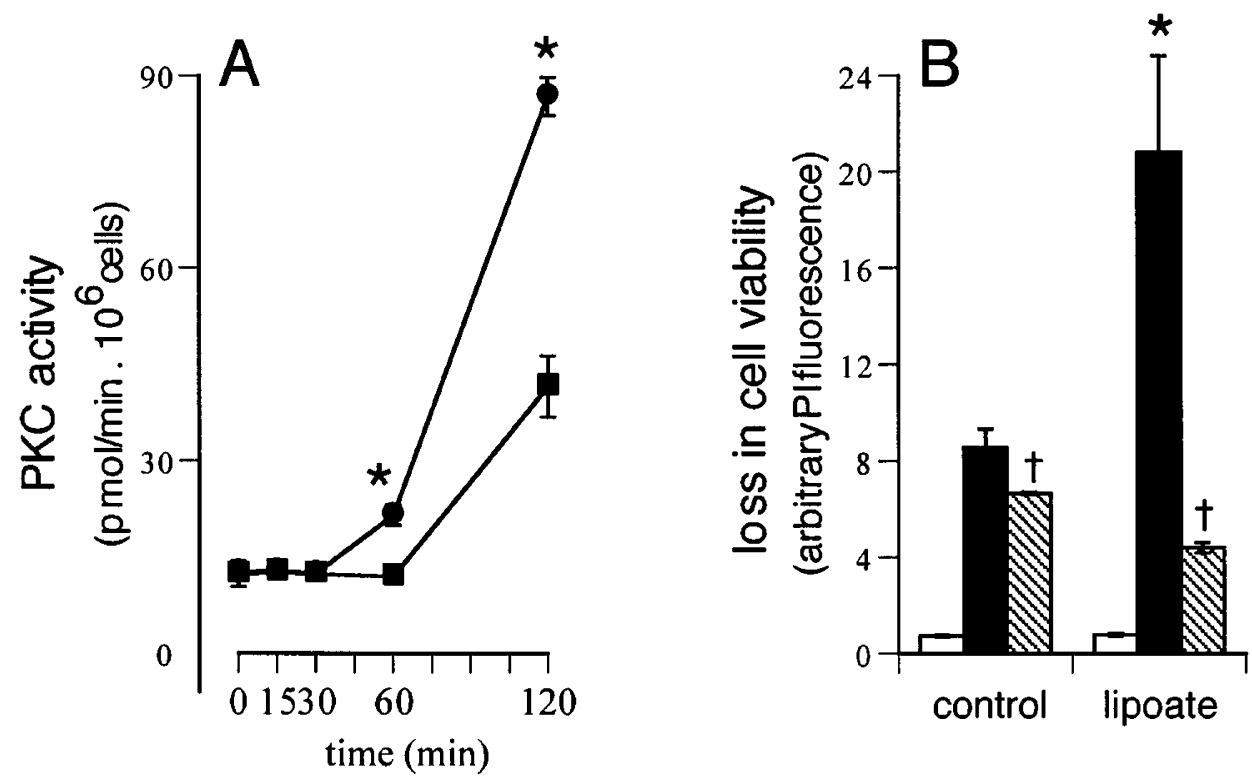

Figure 7 Protein kinase C (PKC) activity and its role in Fas mediated apoptosis of Jurkat cells. (A) Activation of PKC in Fas activated cells. Cells were either not (square) or treated (circle) with $100 \mu \mathrm{M} \mathrm{LA}$ for $72 \mathrm{~h}$. After this treatment, cells were treated or not ( 0 min) with the agonistic Ab $\mathrm{CH} 11$ ( $200 \mathrm{ng} / \mathrm{ml}$ ) for the indicated duration. PKC activity was measured from permeabilized cells. ${ }^{*} P<0.001$ compared to LA non-treated cells. (B) The potentiating effect of LA on Fas mediated cell death was abrogated by inhibition of PKC $\delta$ activity. Cells were either not (control) or treated (lipoate) with $100 \mu \mathrm{M} \mathrm{LA} \mathrm{for} 72 \mathrm{~h}$. After this treatment, cells were treated or not (open bar) with the agonistic $\mathrm{Ab} \mathrm{CH} 11(200 \mathrm{ng} / \mathrm{ml})$ for $4 \mathrm{~h}$ in the absence (solid bar) or presence (hatched bar) of $10 \mu \mathrm{M}$ of rottlerin, a PKC $\delta$ inhibitor with $\mathrm{IC}$. 3-6 $\mu \mathrm{M}$. Rottlerin was added to cells $15 \mathrm{~min}$ before $\mathrm{CH} 11$ treatment. Loss of cell viability was determined on the basis propidium iodide staining of nonpermeabilized cells. Mean fluorescence values are plotted. Data are mean \pm S.D. ${ }^{*} P<0.001$ compared to the corresponding LA non-treated $\mathrm{CH} 11$ treated cells. $\uparrow P<0.001$ compared to the corresponding rottlerin non-treated $\mathrm{CH} 11$ treated cells

A

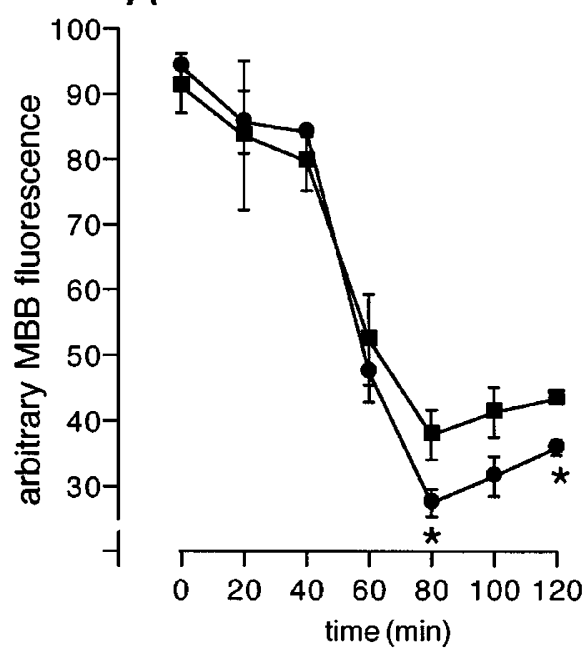

B

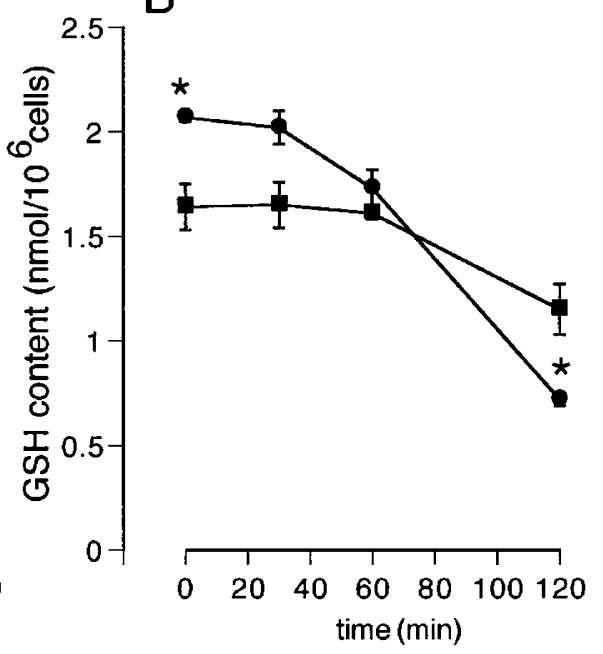

Figure 8 Loss of cellular thiols during Fas mediated apoptosis. Cells were either not (square) or treated (circle) with $100 \mu \mathrm{M}$ LA for $72 \mathrm{~h}$. After this treatment, cells were treated or not $(0 \mathrm{~min})$ with the agonistic $\mathrm{Ab} \mathrm{CH} 11(200 \mathrm{ng} / \mathrm{ml})$ for the indicated duration. (A) Loss of total protein thiols as determined by monobromobimane staining. (B) Loss of cellular GSH. Data are mean \pm S.D. ${ }^{*} P<0.001$ compared to the corresponding LA non-treated cells 
LA treated cells was faster compared to that from LA nontreated cells (Figure 8B).

\section{Caspase 3 activation}

Activation of the Fas receptor by treatment of cells with the agonistic $\mathrm{Ab} \mathrm{CH} 11$ resulted in rapid increase in the activity of the cysteine protease caspase 3 (Figure 9A). A remarkable observation was that pretreatment of Jurkat cells with LA markedly potentiated $\mathrm{CH} 11$ induced caspase activation. LA treatment doubled $\mathrm{CH} 11$ induced caspase activation that was observed after 1 or $2 \mathrm{~h}$ of Fas receptor activation (Figure 9A). These activity results were confirmed by data from Western blots showing enhanced $\mathrm{CH} 11$ induced cleavage of the
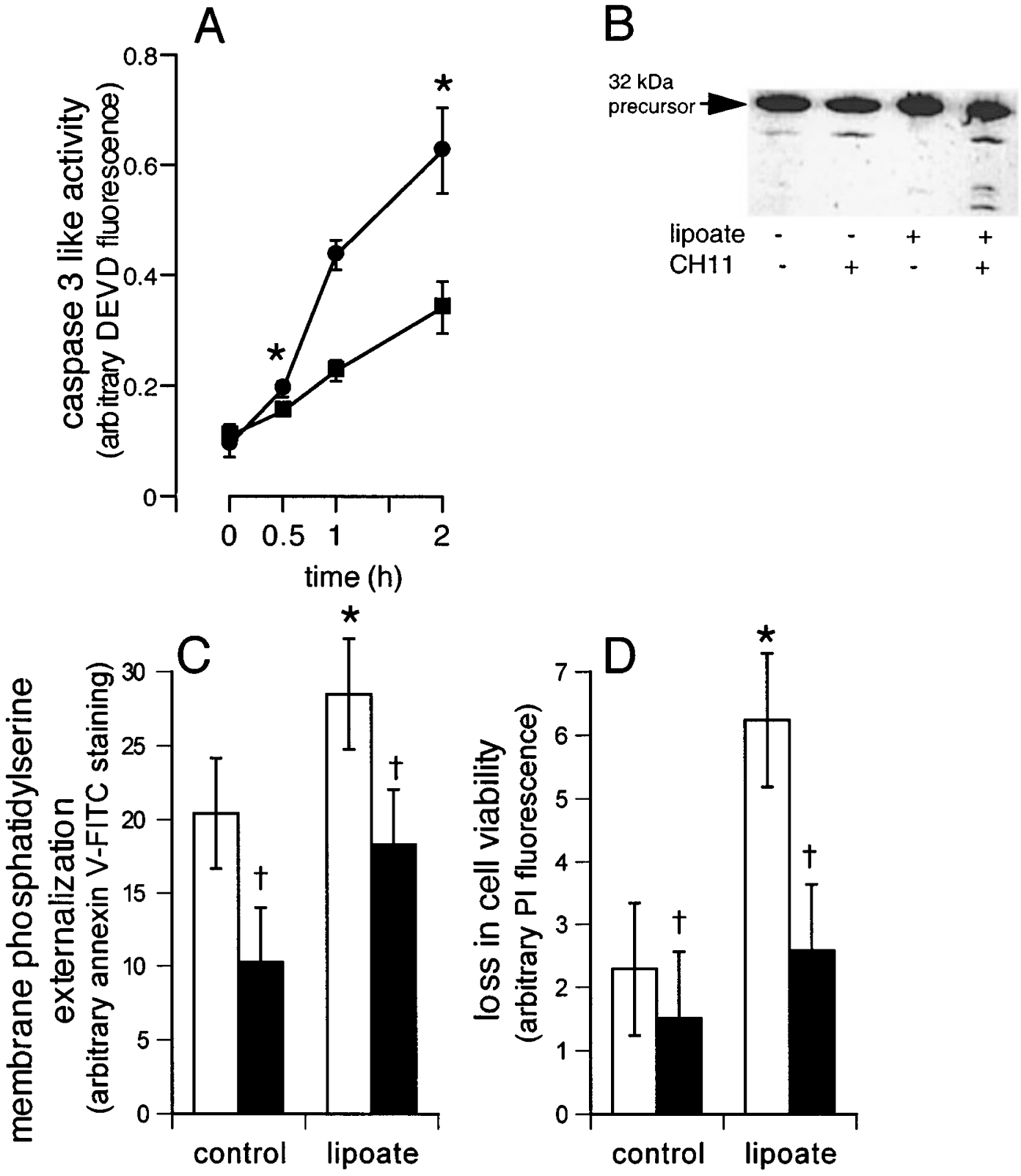

Figure 9 Role of caspase 3 in Fas mediated apoptosis and its potentiation by $\alpha$-lipoic acid. (A) Jurkat cells were either not (square) or treated (circle) with $100 \mu \mathrm{M}$ $\mathrm{LA}$ for $72 \mathrm{~h}$. After this treatment, cells were treated or not $(0 \mathrm{~min})$ with the agonistic $\mathrm{Ab} \mathrm{CH} 11(200 \mathrm{ng} / \mathrm{ml})$ for the indicated duration. ${ }^{*} P<0.001 \mathrm{compared}$ to the corresponding LA non-treated cells. (B) CH11 induced activation of caspase 3 protein as observed by cleavage of the native protein in Jurkat cells. LA treatment (lipoate; $100 \mu \mathrm{M} \mathrm{LA}, 72 \mathrm{~h}$ ) potentiated $\mathrm{CH} 11$ induced $(200 \mathrm{ng} / \mathrm{ml}, 1 \mathrm{~h}$ ) caspase 3 cleavage. (C) Treatment of Jurkat cells with $25 \mu \mathrm{M}$ of caspase-3 inhibitor II (solid bars) inhibited membrane phosphatidylserine externalization in both LA non-treated and LA treated cells. (D) Caspase-3 inhibitor II inhibited CH11 induced loss of Jurkat cell viability. This effect was more pronounced in LA treated cells. In the presence of caspase- 3 inhibitor II the potentiating effect of LA on Fas mediated apoptosis was completely abrogated. Loss of cell viability was determined on the basis propidium iodide staining of non-permeabilized cells. In line and bar graphs shown data are mean \pm S.D. ${ }^{\star} P<0.001$ compared to the corresponding LA non-treated cells; $\dagger P<0.01$ compared to the corresponding caspase- 3 inhibitor II nontreated cells 

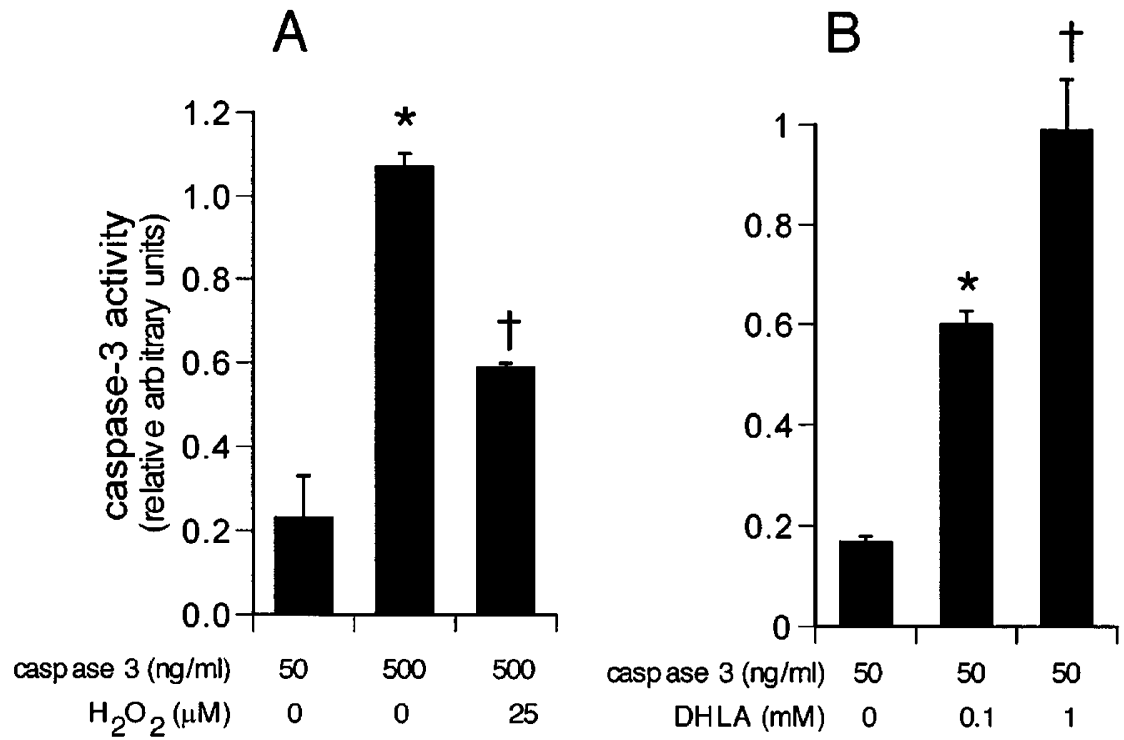

Figure 10 Dihydrolipoate potentiates the activity of purified active recombinant human caspase 3 . (A) Dose-dependent activity of active recombinant human caspase 3 and inhibition of activity in the presence of hydrogen peroxide. Activity of the protein (at the indicated concentrations) was measured in the absence or presence of $25 \mu \mathrm{M}$ hydrogen peroxide in the assay mixture. ${ }^{*} P<0.001$ higher compared to the activity of $50 \mathrm{ng} / \mathrm{ml}$ protein; $\uparrow P<0.001$ lower compared to the activity of $500 \mathrm{ng} / \mathrm{ml}$ protein. (B) Activity of $50 \mathrm{ng} / \mathrm{ml}$ of caspase 3 was measured in the absence or presence of dihydrolipoate (DHLA) as indicated in the figure. ${ }^{*} P<0.001$ higher compared to the activity of $50 \mathrm{ng} / \mathrm{ml}$ protein; $\dagger P<0.001$ higher compared to the activity of $50 \mathrm{ng} / \mathrm{ml}$ protein in the presence of $100 \mu \mathrm{M}$ DHLA

caspase 3 protein in LA treated cells compared to LA nontreated cells (Figure 9B). In cells that were treated with a caspase 3 inhibitor, $\mathrm{CH} 11$ induced apoptosis as indicated by externalization of membrane phosphatidylserine and loss of cell viability was significantly inhibited. In these inhibitor treated cells, the potentiating effect of LA on Fas mediated apoptosis was markedly diminished (Figure $9 \mathrm{C}$ and $\mathrm{D}$ ).

To test whether LA or DHLA may directly influence the activity of caspase 3 the activity of $50 \mathrm{ng} / \mathrm{ml}$ of the recombinant active enzyme was studied. When used at adequate concentration this enzyme was observed to have high activity that was inhibited in the presence of an oxidant, hydrogen peroxide (Figure 10A). DHLA markedly stimulated the activity of recombinant caspase 3 (Figure 10B). However, the presence of LA in the enzyme activity assay mixture did not influence caspase 3 activity (not shown).

\section{Discussion}

\section{Potentiation of Fas mediated cell death}

Signal transduction pathways leading to apoptosis have been of outstanding interest in biotechnology mostly because successful apoptotic agents could in principle treat diseases like cancer with greater specificity and few side effects. ${ }^{32}$ Therapeutic potential of the Fas/FasL system has been evident in several studies. ${ }^{1-3,33}$ We observed that the agonistic anti-Fas $\mathrm{Ab}$ did not induce apoptosis in PBL isolated from healthy human although $30 \%$ cells tested Fas+. Comparing results on the presence (Figure 4A) and abundance (Figure 4B) of Fas receptors in Jurkat and PBL it is evident that the density of Fas receptor in PBL was many-fold lower. Previously it has been shown that a critical level of expression of Fas/APO-1 is a prerequisite for induction of apoptosis. ${ }^{34}$ LA showed a remarkable ability to potentiate Fas mediated cell death in leukemic Jurkat cells, but not in healthy PBL. Previously chemotherapeutic agents such as doxuribicin and vincristine, and the alkaloid taxol have been shown to facilitate Fas mediated cell death. ${ }^{2,33}$ Doxorubicin, vincristine and taxol are anti-tumor drugs that are used for cancer therapy. At high concentrations these agents per se are toxic to cells. In contrast, LA is a safe nutrient mostly known for its ability to bolster cellular glutathione levels, alter intracellular redox state and help protect against diabetic complications. ${ }^{15,17,22}$ This work presents first evidence showing that the redox active agent, LA, may potentiate Fas mediated death in leukemic Jurkat cells. This observation is consistent with a previous report showing that reactive oxygen species such as superoxide anion functions as a natural inhibitor of Fas mediated cell death ${ }^{7}$ since DHLA is known to quench superoxide anions. ${ }^{16}$

\section{Redox regulation of caspase activity}

Because the potentiating effect of LA treatment on Fas mediated apoptosis was observed in one of the earliest markers of apoptosis, externalization of membrane phosphatidyl serine, it might be suspected that LA regulates one or more early intracellular events. Expression of the Fas receptor was not influenced by LA treatment suggesting that LA may have influenced intracellular events signaling for apoptosis. An early event in Fas mediated apoptosis that was strikingly influenced by LA treatment was the activation of the cysteine death protease CPP32 or caspase 3 . The potentiating effect of LA treatment on Fas mediated apoptosis of Jurkat cells was markedly decreased by a caspase 3 inhibitor indicating that 
indeed increased caspase 3 activity in LA-treated Fasactivated cells played a significant role in potentiating cell death. Caspases are known to play a central role in Fas mediated apoptosis of Jurkat cells. ${ }^{10}$ Fas sequentially activates caspase-like proteases that lead to nuclear damage. $^{35}$ It has been suggested that the regulation of caspase activity may be of significance in pathologies where manipulation of apoptosis is expected to have therapeutic significance. $^{10}$

The putative active site of caspase 3 contains a cysteine residue. ${ }^{23}$ In several signaling proteins active site cysteine residues have been shown to be a redox sensitive site. ${ }^{13,14}$ Indeed caspase 3 has been shown to be redox sensitive in a number of studies. This information, however, has been derived from studies where oxidants and thiol-blocking agents down-regulated caspase 3 activity. ${ }^{8,9,11,12}$ Previously it has been reported that low concentration of hydrogen peroxide inhibits caspase activity in Jurkat cells. ${ }^{8}$ Consistently we observed that the activity of purified caspase 3 protein was inhibited by hydrogen peroxide. This study establishes the other side of the same coin showing that indeed caspase 3 activity may be also potentiated by intracellular reducing agents such as DHLA. This is the first study showing that inducible caspase 3 activity may be up-regulated pharmacologically.

In this work LA, a commonly used nutritional supplement and clinical drug, was used as a tool to manipulate cellular redox status. LA is rapidly taken up by cells and reduced enzymatically to DHLA. ${ }^{16-18}$ The DHLA/LA redox couple has a strong reducing power with $-0.32 \mathrm{~V}$ as the reduction potential. Reduction potential of this redox couple is stronger than all other endogenous redox couples such as GSH/GSSG or NADH/NAD ${ }^{+21}$ The ability of DHLA to reduce protein thiols e.g. thioredoxin has been reported. ${ }^{14,16}$ Thus, the use of LA provides a valid model to test the effect of an uniquely potent intracellular reducing agent DHLA on caspase activation. Previously it has been hypothesized, but not established, that the maintenance of a reducing environment inside the cell is necessary to allow for adequate caspase-activity during apoptosis. ${ }^{8}$ Our results showing potentiated activity response of caspase following Fas activation of LA treated cells lend firm support to this hypothesis and reveal the possibility that intracellular caspase activity in Fas activated cells may be up-regulated by a potent intracellular reducing agent. This contention is further supported by our observation showing that the activity of active recombinant caspase 3 is markedly upregulated in the presence of DHLA. In Jurkat cells phosphatidylserine externalization following Fas activation is dependent on death protease activation. ${ }^{25}$ Thus, accelerated externalization of phosphatidylserine in LAtreated Fas-activated cells may be because of higher death protease activity in these cells compared to the corresponding LA non-treated cells.

\section{Loss of mitochondrial membrane potential and increase in $\left[\mathrm{Ca}^{2+}\right]_{i}$}

Fas receptor activation was followed by rapid loss of mitochondrial membrane potential. LA may have caused a more significant loss of mitochondrial function 90 min after Fas-activation via increased caspase 3 activity. Death protease activity has been shown to contribute to events leading to the loss of mitochondrial function in Fas activated Jurkat cells. ${ }^{24}$ Caspase activity also disrupts mitochondrial barrier function. ${ }^{36}$ Following Fas receptor activation, activity of caspase 3 in LA treated cells was markedly higher than that in LA non-treated cells. Loss of mitochondrial membrane potential in Fas activated Jurkat cells was accompanied by a marked increase in $\left[\mathrm{Ca}^{2+}\right]_{i}$. Our results show that after Fas activation cell shrinking is preceded by increased $\left[\mathrm{Ca}^{2+}\right]_{i}$ suggesting a possible role of $\left[\mathrm{Ca}^{2+}\right]_{i}$ in this type of apoptosis. $\mathrm{Ca}^{2+}$ is released from functionally compromised mitochondria. ${ }^{37}$ Other sources such as $\mathrm{Ca}^{2+}$ release from sarcoendoplasmic reticulum pool may not be ruled out, however. After $2 \mathrm{~h}$ of Fas activation, $\left[\mathrm{Ca}^{2+}\right]_{\mathrm{i}}$ may increase to $500 \mathrm{nM}-$ $1 \mu \mathrm{M}^{38}$ At such a concentration range, $\left[\mathrm{Ca}^{2+}\right]_{i}$ may cause caspase- 3 activation. ${ }^{39}$ Thus, loss of mitochondrial function may be visualized as a part of a vicious cycle set on by caspase 3 activity, followed by increased $\left[\mathrm{Ca}^{2+}\right]_{\mathrm{i}}$, which in turn further potentiates the activity of caspase-3.

\section{Involvement of protein kinase $\mathbf{C}$ activity}

Our results show that increased $\left[\mathrm{Ca}^{2+}\right]_{i}$ in Fas activated Jurkat cells is associated with marked activation of PKC. Activation of PKC in Fas activated cells was markedly potentiated in response to LA treatment. Because LA treatment also potentiated Fas mediated apoptosis these results suggest that Fas mediated PKC activation may have contributed to the apoptosis process. To verify this hypothesis we sought to test whether PKC activity inhibition prevents Fas mediated apoptosis. Because most inhibitors of PKC activity are toxic our intent was to find an inhibitor that would be safely tolerated by cells. Rottlerin, a $\mathrm{PKC} \delta$ inhibitor $\left(\mathrm{IC}_{50} 3-6 \mu \mathrm{M}\right)$, matched this criteria. Our observation that rottlerin significantly inhibited Fas mediated apoptosis in LA non-treated cells suggests that $\mathrm{PKC} \delta$ activity may be involved in mediating Fas mediated apoptosis in Jurkat cells. This contention is firmly supported by our observation in LA treated cells showing that the potentiating effect of LA on Fas mediated apoptosis of Jurkat cells is completely abrogated by rottlerin. Previous studies have shown that PKC $\delta$ is activated by CPP32 or caspase 3 at the onset of apoptosis induced by anti-Fas $\mathrm{Ab}$. Such proteolytic activation of $\mathrm{PKC} \delta$ is known to contribute to phenotypic changes associated with apoptosis. ${ }^{40}$ Also, transfection of recombinant protein coding for the catalytic fragment of $\mathrm{PKC} \delta$ results in the apoptotic morphology of cells and nuclei supporting that $\mathrm{PKC} \delta$ activity is indeed involved in mediating Fas mediated apoptosis. ${ }^{26}$

In summary, this study provides first evidence showing that inducible caspase 3 activity may be pharmacologically up-regulated by intracellular reducing agents such as DHLA. Both mitochondria and $\mathrm{PKC} \delta$ are targets of caspase 3 activity. In cells where the Fas receptor is activated, the loss of mitochondrial function is a part of a vicious cycle set on by caspase 3 activity, followed by increased $\left[\mathrm{Ca}^{2+}\right]_{i}$, which in turn further potentiates the activity of caspase-3 leading to cell death. 


\section{Materials and Methods}

\section{Cell culture}

Jurkat T-cell culture Human acute leukemic Jurkat T-cells (clone E61, American Type Culture Collection, ATCC, Bethesa, MD, USA) were grown in RPMI 1640 medium (Gibco BRL, Gaithersburg, MD, USA) supplemented with $10 \%$ FCS, $100 \mathrm{U} / \mathrm{ml}$ penicillin and $100 \mu \mathrm{g} / \mathrm{ml}$ streptomycin, $110 \mathrm{mg} / \mathrm{L}$ sodium pyruvate and $2 \mathrm{mM}$ L-glutamine (University of California, San Francisco, USA). Cells were maintained in a standard culture incubator with humidified air containing $5 \% \mathrm{CO}_{2}$ at $37^{\circ} \mathrm{C}$.

Isolation and culture of human peripheral blood lymphocytes Blood drawn from healthy male volunteers was collected in heparinized tubes. PBL were isolated by a standard density gradient separation on Ficoll-Hypaque (Pharmacia, Sweden) as described previously. ${ }^{22} \mathrm{PBL}$ were seeded at $1 \times 10^{6}$ cells $/ \mathrm{ml}$ in RPMl 1640 culture medium containing $10 \%$ heat inactivated FCS and maintained in a standard culture incubator with humidified air containing $5 \% \mathrm{CO}_{2}$ at $37^{\circ} \mathrm{C}$.

\section{Cell treatment and induction of apoptosis}

Cells were resuspended in standard culture medium and seeded at a density of $1 \times 10^{6}$ cells $/ \mathrm{ml}$. Aqueous stock solution of LA (racemate mixture, ASTA Medica, Frankfurt, Germany) was prepared fresh for each experiment. As indicated in figure legends, cells were pretreated or not with $100 \mu \mathrm{M}$ LA for $72 \mathrm{~h}$. Apoptosis was induced by treating the cells in culture with $200 \mathrm{ng} /$ $\mathrm{ml}$ of an agonistic anti-human Fas $\operatorname{IgM} \mathrm{Ab}$ (clone $\mathrm{CH} 11$ ), Immunotech, Cedex, France). Stock solutions of caspase-3 inhibitor II (Calbiochem, La Jolla, CA, USA) and PKC- $\delta$ inhibitor, Rottlerin (Calbiochem, La Jolla, CA, USA), were prepared in DMSO.

\section{Flow cytometric analyses}

All flow cytometric assays were carried out using either XL or EPICS Elite (Coulter Corporation, Miami, FL, USA) instrument. The forward scatter and side scatter properties of cells were used to establish size gates and exclude cellular debris. In each sample at least 10000 gated cells were examined.

\section{Membrane phosphatidylserine externalization}

To detect phosphatidyl serine externalization on the outer leaflet of plasma membrane, the cells were stained with annexin $\mathrm{V}$ coupled to FITC (Clonetech Inc., Palo Alto, CA, USA). Cells with FITCconjugated annexin $\mathrm{V}$ were excited using a $488 \mathrm{~nm}$ argon ion laser and emission of FITC was recorded at $525 \mathrm{~nm}$ using a flow cytometer.

\section{Cell viability}

Plasma membrane integrity of all cells were determined flow cytometrically using the non-permeant DNA intercalating dye propidium iodide (PI, Molecular Probes, Eugene, OR, USA) that is generally excluded by viable cells. A $15 \mathrm{~mW}$ powered argon ion laser was used for excitation at $488 \mathrm{~nm}$ and PI fluorescence emission signal was collected at $575 \mathrm{~nm}$. PI fluorescence values were used to estimate loss of cell viability.

\section{Determination of DNA fragmentation in agarose gels}

Cells $\left(10 \times 10^{6}\right)$ were suspended in $5 \mu$ l distilled water containing $50 \mathrm{mg} / \mathrm{ml}$ RNAse A. The suspension was incubated at room temperature for $20 \mathrm{~min}$. After this, $5 \mu \mathrm{l}$ of loading buffer $(40 \%$ sucrose, $0.25 \%$ bromophenol blue) was added to the cell suspension. The sample was then electrophoresed through a digestion gel $(0.8 \%$ agarose gel prepared with TBE $[90 \mathrm{mM}$ Tris, $2 \mathrm{mM}$ EDTA and $90 \mathrm{mM}$ boric acid, $\mathrm{pH} 8.4$ ], 2\% sodium dodecyl sulfate and $25 \mathrm{mg} / \mathrm{ml}$ proteinase $\mathrm{K}$ ) followed by separation of DNA in $1.8 \%$ agarose gel. Electrophoresis was carried out in TBE at $20 \mathrm{~V}$. Ethidium bromide stained DNA was visualized under UV illumination.

\section{Flow cytometric determination of DNA fragmentation}

This measurement was done using permeabilized cells as previously described ${ }^{27}$ with some minor modifications. In brief, cells were washed with D-PBS and fixed for $20 \mathrm{~min}$ on ice by resuspending the pellet in $1 \%$ paraformaldehyde in D-PBS. The fixed cells were then centrifuged $(600 \times g$, for $5 \mathrm{~min})$ and gently resuspended in a hypotonic propidium iodide solution $(50 \mathrm{mg} / \mathrm{ml}$ in $0.1 \% \mathrm{w} / \mathrm{v}$ sodium citrate and $0.1 \% \mathrm{v} / \mathrm{v}$ Triton $\mathrm{X}-100)$. The suspension was incubated at $4{ }^{\circ} \mathrm{C}$ in dark for $12-14 \mathrm{~h}$ before being analyzed by a flow cytometer. A $15 \mathrm{mV}$ powered argon ion laser was used for excitation at $488 \mathrm{~nm}$ and emission was measured at $575 \mathrm{~nm}$.

\section{Expression of Fas Ag (CD95)}

Cells were incubated with FITC labeled anti-human Fas (CD95) monoclonal $\mathrm{Ab}$ (Immunotech, Cedex, France) for $30 \mathrm{~min}$ at $4^{\circ} \mathrm{C}$. Cells were then washed twice in Dulbecco's PBS, pH 7.4 (D-PBS) and finally resuspended in D-PBS. Expression of Fas was immediately determined using a flow cytometer. Appropriate isotype control was used to determine background fluorescence. Cells with FITCconjugated antibodies were excited using a $488 \mathrm{~nm}$ argon ion laser and emission of FITC was recorded at $525 \mathrm{~nm}$.

\section{Assessment of mitochondrial membrane potential}

Mitochondrial membrane potential was measured flow cytometrically using 5,5,6,6,-tetrachloro-1,1,3,3-tetraethylbenzimidazolcarbocyanine iodide (JC-1; Molecular Probes, Eugene, OR, USA). ${ }^{28}$ This probe is able to selectively enter into mitochondria, exists in a monomeric form emitting at $527 \mathrm{~nm}$ (green fluorescence) after excitation at $490 \mathrm{~nm}$. However, depending on the mitochondrial membrane potential, JC- 1 is able to form J-aggregates that are associated with a large shift in emission $(590 \mathrm{~nm}$, red fluorescence). Thus, the color of the dye changes reversibly from green to greenish orange as the mitochondrial membrane becomes more polarized. For loading of $\mathrm{JC}-1$, cells $\left(1 \times 10^{6}\right)$ were resuspended in $1 \mathrm{ml}$ of medium and incubated with $10 \mu \mathrm{g} / \mathrm{ml}$ of $\mathrm{JC}-1$ for $10 \mathrm{~min}$ at $37^{\circ} \mathrm{C}$ before analysis. Both red and green (not shown) fluorescence emissions were analyzed using the FL-1 and FL-2 channels of a flow cytometer.

\section{Determination of changes in intracellular $\mathrm{Ca}^{2+}$}

Cells grown in $10 \%$ FCS containing medium either with or without LA were pelleted $(125 \times g, 5 \mathrm{~min})$ and resuspended in Isocove's Modified Dulbecco Medium (IMDM, Gaithersburg, MD, USA) and then activated with $\mathrm{CH} 11$. Calcium flux was measured in indo-1 (Molecular Probes, 
Eugene, OR, USA) loaded cells as described previously. ${ }^{20}$ Experiments were carried out either in the presence of $1 \mathrm{mM}$ of the extracellular calcium chelator EGTA (Sigma, MO, USA) to follow CH11 induced mobilization of intracellular calcium reserves.

\section{Determination of protein kinase C (PKC) activity from whole cells}

Cells in culture were washed twice with D-PBS and resuspended in reaction buffer $(5.2 \mathrm{mM} \mathrm{MgCl}, 94 \mathrm{mM} \mathrm{KCl}, 12.5 \mathrm{mM}$ HEPES, $12.5 \mathrm{mM} \mathrm{EGTA}$, and $8.2 \mathrm{mM} \mathrm{CaCl}_{2}, \mathrm{pH} 7.4$ ) into $200 \mu \mathrm{l}$ portions $\left(0.1 \times 10^{6}\right.$ cells $)$. The measurement of PKC activity was started by addition of streptolysin-O (0.3 IU, Sigma, St. Louis, MO, USA) mixed with $\left[\gamma-{ }^{32}\right.$ P]ATP $(300-450$ c.p.m./pmol, final concentration $250 \mu \mathrm{M}$, DuPont, NEN, Boston, MA, USA), and $100 \mu \mathrm{M}$ peptide substrate (ProLeu-Ser-Arg-Thr-Leu-Ser-Val-Ala-Ala-Lys-Lys, Sigma, St. Louis, MO, USA). After $10 \mathrm{~min}$ incubation at $37^{\circ} \mathrm{C}$, the reaction was stopped by addition of $100 \mu \mathrm{l}$ of $25 \%$ trichloroacetic acid in $2 \mathrm{M}$ acetic acid. The samples were left on ice for $10 \mathrm{~min}$ and then centrifuged to remove the proteins. Samples ( $25 \mu \mathrm{l}$ each) were then spotted on phosphocellulose disc papers (Gibco BRL, Gaithersburg, MD, USA). The disc papers were washed twice with $1 \%$ phosphoric acid, and twice with deionized water. The total radioactivity on each disc was determined using liquid scintillation analyzer. The background phosphorylation in the absence of the substrate peptide was subtracted from all samples. To determine the specificity of results obtained for PKC, an additional measurement of the enzyme activity was done using the pseudosubstrate PKC peptide inhibitor (Arg-Phe-Ala-Arg-Lys-Gly-Ala-Leu-ArgGln-Lys-Asn-Val-His-Glu-Val-Lys-Asn; Sigma, St. Louis, MO, USA) as reported previously. ${ }^{29}$

\section{Flow cytometric determination of cellular sulfhydryls}

Cellular sulfhydryls were determined flow cytometrically using the thiol probe monobromobimane (MBB, Molecular Probes, Eugene, OR, USA) as described previously. ${ }^{22}$ MBB was dissolved in acetonitrile to obtain a $8 \mathrm{mM}$ stock concentration. Cells were pelleted $(125 \times \mathrm{g}, \times$ for $5 \mathrm{~min}$ ) and resuspended in PBS (pH 7.4) at $10^{6}$ cells $/ \mathrm{ml}$. MBB stock solution was added to the cell suspension such that the final concentration of the bimane reagent was $40 \mu \mathrm{M}$. Bimane loaded cells were excited using a $20 \mathrm{~mW}$ powered UV line of a Innova 90-4 argon ion laser (Coherent, Palo Alto, CA, USA) set at $350 \mathrm{~nm}$ in a flow cytometer. Fluorescent emission from cellular sulfhydryl reacted bimane was recorded using a $450 \mathrm{~nm}$ band pass filter.

\section{HPLC determination of glutathione}

Cells were pelleted $(125 \times \mathrm{g}$, for $5 \mathrm{~min})$ and deproteinized by treatment with $4 \%$ monochloroacetic acid. Following the acid treatment, the mixtures were snap-frozen in liquid nitrogen and stored at $-80^{\circ} \mathrm{C}$ for the HPLC determination of GSH content using a coulometric detector as described previously. ${ }^{18}$ The electrodes of the coulometric detector for GSH assays were set at following potentials: electrode 1, $+0.40 \mathrm{~V}$; electrode 2, +0.85 V; and guard cell, $+0.90 \mathrm{~V}$. GSH was separated using a C-18 column $(150 \mathrm{~mm}$ long $\times 4.6 \mathrm{~mm}$ i.d., $5 \mu \mathrm{m}$ pore size; Alltech, Deerfield, IL, USA) and a mobile phase consisting of $98 \%$ $50 \mathrm{mM} \mathrm{NaH} \mathrm{PO}_{4}(\mathrm{pH} 2.7)$ and $2 \%$ acetonitrile. The flow rate was maintained at $1 \mathrm{ml} / \mathrm{min}$ throughout the analysis. Data were collected using a PE Nelson 900 series interface and analyzed using the software Turbochrom 3 (Perkin Elmer, San Jose, CA, USA).

\section{CPP32 or caspase 3 like activity}

Cell pellets were lysed in PBS containing $0.2 \% \mathrm{v} / \mathrm{v}$ Triton X-100 on ice for $10 \mathrm{~min}$. The cell lysates were centrifuged at $10000 \times g$ for $5 \mathrm{~min}$ and clear supernatants were collected and placed on ice. The cell extracts (50 $\mu \mathrm{g}$ protein) were incubated with $60 \mu \mathrm{M}$ of a fluorigenic caspase- 3 substrate (Ac-DEVD-AMC, Calbiochem, La Jolla, CA, USA) in incubation buffer (5 mM dithiothreitol, $50 \mathrm{mM} \mathrm{HEPES,} \mathrm{10 \%} \mathrm{sucrose,}$ $0.1 \%$ CHAPS, $\mathrm{pH} 7.5$ ) for $20 \mathrm{~min}$. The activity of purified active recombinant human caspase 3 protein (Pharmingen, San Diego, CA, USA) was studied using the above mentioned conditions except that the reaction mixture did not contain dithiothreitol. The reaction was halted with $10 \%$ sodium dodecylsulfate. The fluorescence was measured at $380 \mathrm{~nm}$ excitation and $460 \mathrm{~nm}$ emission. ${ }^{30}$

\section{CPP32 or Caspase 3 immunoblot}

For anti-caspase 3 immunoblots, cytosolic extracts of cells were separated on a $13 \%$ SDS-polyacrylamide gel under reducing conditions, transferred to nitrocellulose, and probed with mouse antiCPP32 monoclonal Ab (Transduction Laboratories, Lexington, KY, USA). This was followed by proving with appropriate horseradish peroxidase coupled secondary antibodies (Transduction Laboratories, Lexington, $\mathrm{KY}, \mathrm{USA}$ ). Bound $\mathrm{Ab}$ was detected by enhanced chemiluminescence (ECL, Amersham, Cleveland, $\mathrm{OH}, \mathrm{USA}$ ).

\section{Terminal deoxynucleotidyl transferase (TdT) mediated nick end labeling (TUNEL)}

TUNEL assay was done using the MEBSTAIN ${ }^{\circledR}$ Apoptosis kit (Immunotech Cedex, France). Briefly, cells were washed with PBS and then fixed in $4 \%$ paraformaldehyde at $4{ }^{\circ} \mathrm{C}$ for $30 \mathrm{~min}$ on ice. Cells were washed twice with PBS containing $0.2 \%$ BSA. Proteinase $\mathrm{K}$ was added to the cell pellet. Cells were incubated for $30 \mathrm{~min}$ at $37^{\circ} \mathrm{C}$. Permeabilization of the cells was performed with $1 \mathrm{ml}$ PBS containing $0.5 \%$ Tween and $0.2 \%$ BSA. Cells were incubated in TdT reaction reagent (TdT+biotin-dUTP) for $1 \mathrm{~h}$ at $37^{\circ} \mathrm{C}$. After washing with PBS and blocking, cells were stained with avidin-FITC and analyzed using $a$ flow cytometer.

\section{Statistics}

Data presented are mean \pm S.D. or representative of at least three independent experiments. For flow cytometric measurements mean autofluorescence expressed in arbitrary units have been plotted. Difference between group means was tested by Students $t$-test. The minimum level of significance was set at $P<0.01$.

\section{Acknowledgements}

This study was supported by National Institutes of Health grant GM27345.

\section{References}

1. Shimizu M, Yoshimoto T, Nagata S and Matsuzawa A (1996) A trial to kill tumor cells through Fas (CD95)-mediated apoptosis in vivo. Biochem Biophys Res Commun 228: $375-379$

2. Roth W, Fontana A, Trepel M, Reed JC, Dichgans J and Weller M (1997) Immunochemotherapy of malignant glioma: synergistic activity of CD95 ligand and chemotherapeutics. Cancer Immunol Immunother 44: 55-63

3. Komada Y and Sakurai M (1997) Fas receptor (CD95)-mediated apoptosis in leukemic cells. Leuk Lymphoma 25: 9-21 
4. Sata M, Perlman H, Muruve DA, Silver M, Ikebe M, Libermann TA, Oettgen $P$ and Walsh K (1998) Fas ligand gene transfer to the vessel wall inhibits neointima formation and overrides the adenovirus-mediated T cell response. Proc Natl Acad Sci USA 95: 1213-1217

5. Oridate N, Suzuki S, Higuchi M, Mitchell MF, Hong WK and Lotan R (1997) Involvement of reactive oxygen species in $\mathrm{N}$-(4-hydroxyphenyl)retinamideinduced apoptosis in cervical carcinoma cells [see comments]. J Natl Cancer Inst 89: $1191-1198$

6. McGowan AJ, Bowie AG, LA ON and Cotter TG (1998) The production of a reactive oxygen intermediate during the induction of apoptosis by cytotoxic insult. Exp Cell Res 238: 248-256

7. Clement MV and Stamenkovic I (1996) Superoxide anion is a natural inhibitor of FAS-mediated cell death. Embo J 15: 216-225

8. Hampton MB and Orrenius S (1997) Dual regulation of caspase activity by hydrogen peroxide: implications for apoptosis. FEBS Lett 414: 552-556

9. Mannick JB, Miao XQ and Stamler JS (1997) Nitric oxide inhibits Fas-induced apoptosis. J Biol Chem 272: 24125-24128

10. Longthorne VL and Williams GT (1997) Caspase activity is required for commitment to Fas-mediated apoptosis. Embo J 16: 3805-3812

11. Mohr S, Zech B, Lapetina EG and Brune B (1997) Inhibition of caspase-3 by Snitrosation and oxidation caused by nitric oxide. Biochem Biophys Res Commun 238: $387-391$

12. Takahashi A, Goldschmidt-Clermont PJ, Alnembri ES, Fernandes-Alnemri T, Yoshizawa-Kumagaya K, Nakajima K, Sasada M, Poirier GG and Earnshaw WC (1997) Inhibition of ICE-related proteases (caspases) and nuclear apoptosis by phenylarsine oxide. Exp Cell Res 231: 123-131

13. Sen CK and Packer $L$ (1996) Antioxidant and redox regulation of gene transcription. Faseb J 10: 709-720

14. Sen CK (1998) Redox signaling and the emerging therapeutic potential of thiol antioxidants. Biochem Pharmacol 55: 1747-1758

15. Ziegler D and Gries FA (1997) Alpha-lipoic acid in the treatment of diabetic peripheral and cardiac autonomic neuropathy. Diabetes 46 (suppl 2): S62 - S66

16. Packer L, Roy S and Sen CK (1997) Alpha-lipoic acid: a metabolic antioxidant and potential redox modulator of transcription. Adv Pharmacol 38: 79-101

17. Sen CK (1997) Nutritional biochemistry of cellular glutathione. J Nutr Biochem 8 : $660-672$

18. Sen CK, Roy S, Khanna S and Packer L (1999) Determination of oxidized and reduced lipoic acid using high performance liquid chromatography and coulometric detection. Meth Enzymol 299: 239-246

19. Handelman GJ, Han D, Tritschler H and Packer L (1994) Alpha-lipoic acid reduction by mammalian cells to the dithiol form, and release into the culture medium. Biochem Pharmacol 47: 1725-1730

20. Sen CK, Roy S and Packer L (1996) Involvement of intracellular Ca2+ in oxidantinduced NF-kappa B activation. FEBS Lett 385: 58-62

21. Jocelyn PC (1967) The standard redox potential of cysteine-cystine from the thiol-disulfide exchange reaction with glutathione and lipoic acid. Eur J Biochem 2: $327-331$

22. Sen CK, Roy S, Han D and Packer L (1997) Regulation of cellular thiols in human lymphocytes by alpha-lipoic acid: a flow cytometric analysis. Free Radic Biol Med 22: $1241-1257$

23. Fernandes-Alnemri T, Litwack $G$ and Alnemri ES (1994) CPP32, a novel human apoptotic protein with homology to Caenorhabditis elegans cell death protein Ced-3 and mammalian interleukin-1 beta-converting enzyme. J Biol Chem 269: $30761-30764$

24. Krippner A, Matsuno-Yagi A, Gottlieb RA and Babior BM (1996) Loss of function of cytochrome $c$ in Jurkat cells undergoing fas-mediated apoptosis. J Biol Chem 271: $21629-21636$
25. Martin SJ, Finucane DM, Amarante-Mendes GP, O'Brien GA and Green DR (1996) Phosphatidylserine externalization during CD95-induced apoptosis of cells and cytoplasts requires ICE/CED-3 protease activity. J Biol Chem 271: 28753-28756

26. Mizuno K, Noda K, Araki T, Imaoka T, Kobayashi Y, Akita Y, Shimonaka M, Kishi Sand OhnoS (1997) The proteolytic cleavage of protein kinase C isotypes, which generates kinase and regulatory fragments, correlates with Fas-mediated and 12-O-tetradecanoyl-phorbol-13-acetate-induced apoptosis. Eur J Biochem 250 $7-18$

27. Nicoletti I, Migliorati G, Pagliacci MC, Grignani F and Riccardi C (1991) A rapid and simple method for measuring thymocyte apoptosis by propidium iodide staining and flow cytometry. J Immunol Methods 139: 271-279

28. Smiley ST, Reers M, Mottola-Hartshorn C, Lin M, Chen A, Smith TW, Steele Jr GD and Chen LB (1991) Intracellular heterogeneity in mitochondrial membrane potentials revealed by a J-aggregate-forming lipophilic cation JC-1. Proc Natl Acad Sci USA 88: 3671-3675

29. Alexander DR, Graves JD, Lucas SC, Cantrell DA and Crumpton MJ (1990) A method for measuring protein kinase $C$ activity in permeabilized T lymphocytes by using peptide substrates. Evidence for multiple pathways of kinase activation. Biochem J 268: 303-308

30. Rodriguez I, Matsuura K, Ody C, Nagata S and Vassalli P (1996) Systemic injection of a tripeptide inhibits the intracellular activation of CPP32-like proteases in vivo and fully protects mice against Fas-mediated fulminant liver destruction and death. J Exp Med 184: 2067-2072

31. GschwendtM, MullerHJ, Kielbassa K, Zang R, Kittstein W, Rincke Gand Marks F (1994) Rottlerin, a novel protein kinase inhibitor. Biochem Biophys Res Commun 199: $93-98$

32. SmaglikP (1998) Biotech firms on quest for apoptotic therapies. The Scientist 12

33. Roth W, Wagenknecht B, Grimmel C, Dichgans J and Weller M (1998) Taxolmediated augmentation of CD95 ligand-induced apoptosis of human malignant glioma cells: association with bcl-2 phosphorylation but neither activation of p53 nor G2/M cell cycle arrest. Br J Cancer 77: 404-411

34. Weller M, Malipiero U, Rensing-Ehl A, Barr PJ and Fontana A (1995) Fas/APO-1 gene transfer for human malignant glioma. Cancer Res 55: 2936-2944

35. Enari M, Talanian RV, Wong WW and Nagata S (1996) Sequential activation of ICE-like and CPP32-like proteases during Fas-mediated apoptosis. Nature 380: $723-726$

36. Marzo I, Susin SA, Petit PX, Ravagnan L, Brenner C, Larochette N, Zamzami N and Kroemer G (1998) Caspases disrupt mitochondrial membrane barrie function. FEBS Lett 427: 198-202

37. Babcock DF, Herrington J, Goodwin PC, Park YB and Hille B (1997) Mitochondrial participation in the intracellular Ca2+ network. J Cell Biol 136 $833-844$

38. Oshimi $Y$ and Miyazaki S (1995) Fas antigen-mediated DNA fragmentation and apoptotic morphologic changes are regulated by elevated cytosolic $\mathrm{Ca} 2+$ level. J Immunol 154: 599-609

39. Takadera T and Ohyashiki T (1997) Apoptotic cell death and caspase 3 (CPP32) activation induced by calcium ionophore at low concentrations and their prevention by nerve growth factor in PC12 cells. Eur J Biochem 249: 8-12

40. Ghayur T, Hugunin M, Talanian RV, Ratnofsky S, Quinlan C, Emoto Y, Pandey P, Datta R, Huang Y, Kharbanda S, Allen H, Kamen R, Wong W and Kufe D (1996) Proteolytic activation of protein kinase $\mathrm{C}$ delta by an ICE/CED 3-like protease induces characteristics of apoptosis. J Exp Med 184: 2399-2404 